Georgetown University Law Center

Scholarship @ GEORGETOWN LAW

2009

\title{
Affordable Housing and the Conflict of Competing Goods: A Policy Dilemma
}

Michael R. Diamond

Georgetown University Law Center, diamondm@law.georgetown.edu

This paper can be downloaded free of charge from:

https://scholarship.law.georgetown.edu/facpub/263

Michael Diamond, Affordable Housing and the Conflict of Competing Goods: A Policy Dilemma in AFFORDABLE HOUSING AND PUBLIC-PRIVATE PARTNERSHIPS (Nestor M. Davidson \& Robin Paul Malloy eds., Farnham, U.K.: Ashgate Press 2009)

This open-access article is brought to you by the Georgetown Law Library. Posted with permission of the author. Follow this and additional works at: https://scholarship.law.georgetown.edu/facpub

Part of the Housing Law Commons 


\section{GEORGETOWN LAW Faculty Publications}

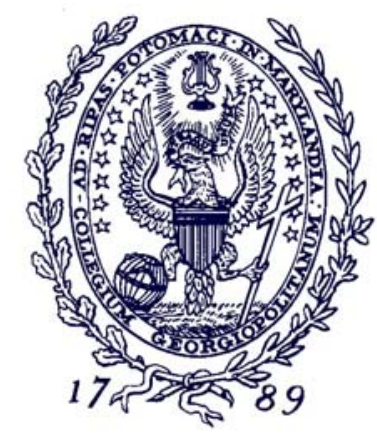

February 2010

Georgetown Public Law Research Paper No. 10-07

\section{Affordable Housing and the Conflict of Competing Goods: A Policy Dilemma} in

\section{AfFordable Housing And Public-Private} PARTNERSHIPS (Nestor M. Davidson \& Robin Paul Malloy eds., Farnham, U.K.: Ashgate Press 2009)

\section{Michael Diamond}

Professor of Law

Georgetown University Law Center

diamondm@law.georgetown.edu

This paper can be downloaded without charge from:

Scholarly Commons: http://scholarship.law.georgetown.edu/facpub/263/

SSRN: $\underline{\text { http: } / / \text { ssrn.com/abstract }=1558474}$

Posted with permission of the author 


\title{
Chapter 1 \\ Affordable Housing and the Conflict of Competing Goods: A Policy Dilemma
}

\author{
Michael Diamond
}

My purpose in this chapter is twofold; first to set out some broad concepts related to affordable housing production; and second, to note some of the dilemmas associated with governmental housing policy. In particular, I want to discuss what I have called the conflict of competing goods, that is, the conflict between various housing goals that most people would agree, at least in the abstract, are socially and morally desirable. The conflict arises because, in a world of finite resources, it is impossible to maximize for each of the competing goals. Society, therefore, is put to the choice among incommensurables. The question is how to make the choice. In this chapter, unfortunately, my goal is limited to pointing out the conflicts and suggesting some of the ways society has, or might, attempt a resolution of these conflicts. Since each of the methods I mention has significant flaws, identifying or creating the perfect resolution will have to wait for future authors.

To begin, there is a wide range of goals that might underlie the promotion of affordable housing and I would like to discuss some of them. Many are obvious while others are much less so, often visible only upon close analysis. Let me suggest some of the major goals sought to be accomplished by policymakers and by advocates of decent, affordable housing. Among the obvious ones are the provision of shelter and the potential creation of wealth.

Perhaps less obvious goals are the growth in psychological well-being due to a resident's sense of "home" and its resulting stability, ${ }^{1}$ the improved physical health of the homeowner's family, ${ }^{2}$ the resident's increased participation in civic society, ${ }^{3}$ and the improved educational performance of their children. ${ }^{4}$ Another goal might be to achieve racial and economic integration in order to allow a wider

1 J. Peter Byrne \& Michael Diamond, Affordable Housing, Land Tenure, and Urban Policy: The Matrix Revealed, 34 Fordham URB. L.J. 527, 550 (2007).

2 Office of the Surgeon General, Healthy People: The Surgeon General's Report on Health Promotion and Disease Prevention 6 (United States Public Health Service 1979).

3 See Jeffrey James Minton, Rent Control: Can and Should It Be Used to Combat Gentrification?, 23 OHı N.U. L. Rev. 823, 835 (1997); see also William H. Simon, SocialRepublican Property, 38 UCLA L. Rev. 1335, 1360-61 (1991).

4 J. Peter Byme, Two Cheers for Gentrification, 46 How. L.J. 405, 423-24 (2003). 
range of residents to partake of the benefits often associated with mixed race and/or mixed income communities, such as greater cultural diversity, more and better municipal services, greater social amenities and the social connections that might lead to better employment opportunities. ${ }^{5}$ Still others might be to enhance housing accessibility for those with disabilities, ${ }^{6}$ to create environmentally friendly housing, ${ }^{7}$ or to preserve the historical and cultural value of the property. ${ }^{8}$

The provision of shelter is probably the most fundamental aspect of affordable housing policy. Yet as of 2005, the Department of Housing and Urban Development estimated a shortage of nearly six million units of affordable housing in the nation and this estimate applies only to worst case needs. ${ }^{9}$ The shortage of decent affordable housing is actually much greater than this and the shortage is growing. ${ }^{10}$ To add to the problem, the private market, under current conditions, has only a limited ability to produce sufficient units to make up the deficit or even to stem the increasing gap. The shortfall results in such societal problems as homelessness, overcrowding, inadequate conditions, and the payment by many households of a disproportionate amount of their income for housing.

Moreover, in the current economic climate, there does not seem to be a viable way to construct sufficient numbers of new affordable units. High land costs, significant local resistance to affordable housing units being placed in certain communities and current political priorities all militate against new construction. So do the economics of unsubsidized units, particularly the limited ability of the poor to pay the actual costs of decent, newly constructed housing. Thus, some attention has been given by policymakers to rehabilitation of existing units. While some of the problems associated with new construction, for example, the placement of affordable housing units, are reduced by calling for rehabilitation of existing units, many other problems, including escalating land costs, persist. In addition, other issues, such as the potential entrenchment of concentrated poverty, may be exacerbated by rehabilitating units to house the poor in existing low income communities.

5 Id.

6 Robert G. Schwemm, Barriers to Accessible Housing: Enforcement Issues in "Design and Construction" Cases Under the Fair Housing Act, 40 U. RICH. L. REv. 753, 756 (2006).

7 See Green Building Act of 2006, D.C. Code $\S$ 6-1451.01 (Supp. 2007).

8 See National Historic Preservation Act, 16 U.S.C $\$ 470$ (2000).

9 Affordable Housing Needs: A Report to Congress on the Significant Need for Housing, 2007 Untted States Department of Housing and Urban Development, Office of Policy Development and Research 14.

10 See Affordable Housing Needs: A Report to Congress on the Significant Need for Housing, 2007 United States Department of Housing and Urban Development, Office of Policy Development and Research 14; see also Affordable Housing Needs: A Report to Congress on the Significant Need for Housing, 2005 UNTtEd StATEs DEPARTMENT OF Housing and Urban Development, Office of Policy Development and Research 14. 
Because of these realities, government policy has had to create incentives for the construction and rehabilitation of affordable units. While there is wide variety in the form of the incentives, they cluster around direct subsidy payments to owners or renters, ${ }^{11}$ income and real estate tax forbearance, ${ }^{12}$ zoning concessions, ${ }^{13}$ and land write-downs. ${ }^{14}$ Unfortunately, because the goals associated with affordable housing policy are so varied, the overall array of policies is incoherent and, in many cases, contradictory. Policies favoring one goal often work, presumably unconsciously, in opposition to others. This characterizes the conflict of competing goods.

One set of conflicting goals that I mentioned earlier is the competition between the provision of decent, affordable shelter and the creation of wealth for homeowners. While each of these goals is laudable, they cannot each be maximized in any particular project. To the extent society seeks to preserve an affordable housing unit for the long term, it must restrict the wealth that an owner can derive from the sale or rental of that property. To the extent the owner is able to demand full market value for the unit, it would likely be too expensive, either as a purchase or as a rental, for a low income resident. However, if the owner is restricted from deriving maximum financial benefit from the property, that owner's wealth creation is restricted, often severely. If the owner does sell the property subject to the restriction, the net proceeds may not be sufficient to buy another unit in the unsubsidized market.

This begs the question of who is the intended beneficiary of governmental housing subsidy programs. It might be the resident who is lucky enough to get the subsidy, either the difference between the market rent and what the resident actually has to pay for the unit or the difference between what a buyer had to pay for the unit and the amount he or she could sell it for. In the homeownership model, the subsidy might be captured by the individual resident which might give that resident the capital to escape poverty. On the other hand, such a sale would take the particular unit out of the pool of affordable housing forever, leaving potential future residents and society one more step away from closing the affordability gap.

Alternatively, the beneficiary could be a class composed of all potential current and future low income residents. This is not unlike what many Native American

11 For example, the Housing Choice Voucher Program, available at http://www.hud. gov/offices/pih/programs/hcv.

12 Norman Alpert, Property Tax Abatement: An Incentive for Low Income Housing, 11 HaRv. J. ON Legis. 1 (1973).

13 Nico Calavita, Kenneth Grimes \& Alan Mallach, Inclusionary Housing in California and New Jersey: A Comparative Analysis, 8 Housing Pol'y Debate 109, 123 (1997).

14 Melvyn R. Durchslag, Property Tax Abatement for Low-Income Housing: An Idea Whose Time May Never Arrive, 30 HaRv. J. ON Legls. 367, 373 (1993). 
groups believe about natural resources, including land. ${ }^{15}$ They believe each person is merely a steward of such resources for all future generations, using what he or she needs and leaving the rest for those yet to come. To protect subsequent users of the property, a deed restriction could be used to limit the equity that each successive owner could take from the sale of the property. In this way, society would be able to preserve the pool of affordable units available to future eligible residents. The cost of such a policy, however, is to leave low income homeowners in these units without the tool that is most likely to raise their living standard; the equity from their home. When residents leave an equity restricted homeownership unit, will they have the wherewithal upon the sale of their unit to purchase a comparable unit in the unsubsidized market?

Another conflict concerning the rehabilitation of existing units is the question of de-concentrating poverty. The literature is replete with examples of the social problems in communities with very high concentrations of very low income residents. ${ }^{16}$ To the extent society desires to de-concentrate poverty and to create mixed income neighborhoods, the result will also be to break up existing communities and to dissolve the ties and local networks that are fundamental to the well-being of many people. On the other hand, to leave high concentrations of poverty intact is to risk misery for many residents of such neighborhoods and further social deterioration. Efforts to repair existing high concentration communities would require very large expenditures while offering only uncertain outcomes. For example, efforts to attract higher income residents to the re-developed, formerly low income areas risks the type of gentrification that results in the involuntary displacement of the lower income residents. The displaced residents often have very limited prospects as to where to move. They often go to other communities with high poverty concentrations or they create new such areas as the influx of lower income residents results in the departure of many current moderate or middle income residents.

Since these policy conflicts have received a good deal of attention in several scholarly outlets, I would like to discuss some of the other, less obvious, policy conflicts. Two have recently created difficulties for affordable housing development in the District of Columbia and have implications for doing so nationally. One is the requirement that projects funded, in whole or in part, by the local government include, at a minimum, 5 percent of the units developed be fully accessible to persons with handicaps. The second is that such buildings include environmentally sound elements, that is, they utilize "green" materials and techniques in their construction. A third conflict is a bit more abstract. It deals with the relationship between historic preservation and the provision of affordable housing. This

15 Paul H. Carlson, The Plains Indians 111 (1998).

16 See, e.g., Karen Seccombe, Families in Poverty in the 1990s: Trends, Causes, Consequences, and Lessons Learned, 62 Journal OF MARRIAGE AND the FAMLY 1094, 11034 (Nov. 2000); Matthew R. Lee, Concentrated Poverty, Race, and Homicide, 41(2) THE SOCIOLOGICAL QUARTERLY 189, 190-94 (Spring 2000). 
conflict arises very graphically when buildings in historic districts, although not themselves historically noteworthy, are to be renovated for the purpose of creating decent and affordable housing for the poor. The historic designation requires that the renovations be done in compliance with the historic nature of the district. This means the materials and designs utilized must be compatible with the historic norm. In many cases, compliance causes the cost of the renovation to rise dramatically.

To put these issues into context, let me refer to a recent experience I had with a client. Not too long ago, I represented a resident association in purchasing the building, which was in one of the poorest neighborhoods in the District of Columbia, in which the members resided. ${ }^{17}$ The association wished to purchase the building, renovate it, and then convert it into an affordable cooperative. As the association developed plans for the acquisition and renovation of the property, we began estimating the cost associated with these plans. We determined that the only way the residents could afford the project would be to finance the acquisition and renovation through programs operated by the District of Columbia's government. ${ }^{18}$ Since the loan terms available from the government were so favorable, borrowing from the City would reduce the financing costs of the project significantly in comparison to the costs associated with a market rate loan. The City loan, however, came with a range of requirements including a deed restriction mandating longterm affordability, the requirement to provide a fully accessible unit in the 15-unit building, and a variety of "green" elements.

Each of these requirements, accessibility, environmental soundness, and historic preservation (which was an issue in another building in which I worked), are laudable elements of public policy. Most would agree, I think, that people with handicaps should be able to participate in all elements of civic society without unnecessary barriers that limit their access to societal involvement and to the broad range of housing available to others. Similarly, most would agree that protecting the environment is a worthwhile goal and that society should take steps to do so. Finally, many who consider the question would say that it is important for society and communities to recognize and preserve their history and culture, including through the maintenance of the traditional appearance of historic neighborhoods. The problem, of course, is that achieving these goals has costs. The costs are not merely the expenditure of additional funds, although all of these goals involve costly elements. There are also opportunity costs associated with each choice society makes. Each choice, as with many policy choices, involves costs to other

17 Such a series of events was possible due to the District of Columbia's Tenant Opportunity to Purchase Act (TOPA), D.C. Code $\S 42-3404.02$ et seq. (2001), which gives tenants in buildings that the owner wishes to sell the opportunity to purchase them, often with financing provided by the District's Department of Housing and Community Development (DHCD).

18 DHCD operates a variety of very low interest rate, long-term loan programs. In addition, the terms of the loan can be negotiated to create a great deal of flexibility. This allows many projects that appear not to be feasible to be completed at an affordable cost. 
laudable social goals in that they reduce resources available to satisfy such other goals.

Let us examine in turn each of the conflicts I mentioned. The requirement of accessibility, particularly in renovations of existing structures, often involves retrofitting structural elements that increase significantly the cost of housing. For example, in the short narrative I presented earlier, the building had no elevator and an entrance way that required one to go up or go down one flight of stairs to gain access to the units, none of which was on ground level. The stairways were not wide enough to permit a stairway lift to be added. Of the various ways to comply with the City's accessibility requirement, only one would preserve the semblance of affordability, yet even that method involved enormous cost.

The residents chose to reconfigure the building by constructing a ramp from the public sidewalk to the side of the building and then along the side of the building to a newly constructed exterior entrance into a unit that had to be built, essentially from scratch, to accommodate the width and amenity requirements of accessibility. This was accomplished by reconfiguring space in what had been the utility room in the basement. This required moving the heating plant and electrical panel to another area of the basement. The cost of making these changes added about 15 percent, or more than $\$ 10,000$, to the cost of each unit. The income of the residents, which ranged from about $\$ 13,000$ per year to approximately $\$ 35,000$, could barely manage the additional monthly burden caused by these changes. And after shouldering this additional load, and despite serious efforts to fill the unit with a person in need of accessible housing, the association has not attracted even a single inquiry from a person in need of such a unit. The cost of constructing the accessible unit, as well as the cost of having the unit remain unoccupied, is borne by the residents of that building through higher monthly housing costs. To the extent that residents, including those with handicaps, have low or very low incomes, the increases in cost associated with accessibility put enormous pressure on the element of affordability, the very purpose of the renovation in the first place.

Similarly, the goal of environmentally friendly buildings also may conflict with the goal of affordability. Green elements and construction are often more expensive than their conventional counterparts, sometimes considerably more expensive. While the up front capital costs of installing green elements in a building are often recaptured by lower operating costs over the life of the project, where affordability is a goal, the question is whether the operating savings in any particular year exceed the increased financing costs for the installation of the green elements. If not, the effect of going green is to increase the current cost of housing for the poor, a cost they can ill afford to absorb. Of course, there are gains to society from using more environmentally friendly materials and techniques but, to a great extent, the costs of doing so are placed upon the poor while the environmental benefits are shared by society as a whole.

The third conflict, that of historic preservation and affordability, arose in the context of another building. In order to do the renovations planned by the residents, 
the building had to comply with the historic district's architectural guidelines. This meant that the exterior had to be maintained in the same architectural style in which it had been built. This became a problem, for example, when new, energy efficient windows were to be installed. There was no standard window that complied with the historic guidelines. Thus, the windows had to be custom made in order to comply with the historical requirements. The same was true of interior moldings which could not be purchased as a stock item. They had to be specially milled. Again, the very high cost of meeting these requirements was borne by the residents, although it is possible, if not probable, that none of them felt that they benefited from the historic preservation.

The concept of competing goods is not new. Forty years ago, Garrett Hardin wrote a well-known essay entitled "The Tragedy of the Commons." 19 Hardin posited a world with finite resources and needs that exceed the ability or willingness of societies to meet them. He asked the question how ought society to choose between competing needs and how should it pay for the needs that are given priority. While Hardin was concerned with the problem of population growth and the ability of the world to provide for the growing population, his conceptual framework is relevant here. How shall we choose, in the universe of varying goals for housing policy, among the large number of competing goods where each cannot be maximized in any particular situation? How shall we allocate the costs of the choices we ultimately make?

There are many theories of how to make the selection among competing goals and I would like to discuss just a few of them. One such theory, public choice, ${ }^{20}$ suggests that individuals will be motivated by their own self-interest regardless of what they might consider the greater societal good. In democracies, where the will of a majority is thought to be the best method for deciding political priorities, the poor are generally at a serious disadvantage. They, almost by definition, lack the political power to achieve their ends. This is true even if one assumes that those ends are held in common among the poor, itself a questionable assumption. Thus, the added costs imposed by implementing these societal goods may fall directly on the poor, while the benefits are distributed more widely through society, a classic free-rider problem.

But just what is one's self-interest? If everyone pursues his or her own interest, how do we account for policies supporting affordable housing? A cynical response might be that the public provides just enough affordable housing to prevent more serious social disruptions. It also might be that the policies in place keep affordable housing mostly cabined in poor neighborhoods, away from the middle class citizens who support such policies. These possibilities suggest a touch of altruism used in service of a more concealed self-interest. Another possibility is less cynical. Policy may be the result of people choosing to do the right thing. This "right thing"

19 Garrett Hardin, The Tragedy of the Commons, SCIENCE, Dec. 13, 1968, at 1243.

20 Thomas Romer \& Howard Rosenthal, The Elusive Median Voter, 12 Journal of Public ECONOMICS 143-70 (1979). 
could arise from a Habermasian discourse,,$^{21}$ the result of which elucidates the appropriate choice. This type of discourse hearkens to the civic republican tradition of participatory democracy.22 Both Habermas and civic republicanism offer the opportunity for participation by those typically excluded by public choice theory. This model, however, offers only a procedural framework within which decisionmaking can take place. It allows discussion, reasoning, and, perhaps, compromise. It does not, however, solve the problem of greater resources or power by one of the discoursing sides. Moreover, there are countless numbers of "right things" and in our current economic situation, doing one right thing may preclude doing some other right thing. We may be in a zero-sum game in which to favor one goal is to deprive another. How should we choose between affordability and accessibility or environmental soundness? Between wealth creation and preservation? I know what I would choose, and why. I also know that others will have sound arguments for different choices. The problems caused by these conflicts sound in morals, politics, and economics. So much of the decision is based on who we are and what we have been brought to believe. I think back to the Rawlsian model put forward in his classic "A Theory of Justice." ${ }^{23}$ What would our housing policy look like if the policymakers were all shrouded by the veil of ignorance? What if they did not know who they were or where they stood in society? In such a case, self-interest would be irrelevant because the policymakers would not be aware of what that interest might be. While I admire the purity of Rawls' model, I am not sure it gets us any closer to deciding, in our world of finite resources, which of the several competing goods should be chosen or to articulating a formula that would help us decide. We must, as Hardin reminds us, make commensurable the incommensurable.

My goal in this chapter, however, has not been to delve into moral or political philosophy but, rather, to point out the incommensurables in current housing policy. Without committing significant new resources to affordable housing, a very unlikely occurrence in today's world, these incommensurables will arise in many housing situations. Neither the policymakers, nor many practitioners, however, seem cognizant of the conflicts which present both policy and practice problems. On the one hand, policymakers need to choose, consciously, what goals to prioritize among the many conflicting ones in affordable housing. On the other hand, practitioners need to be able to maneuver between these goals to achieve satisfactory ends for their clients. In addition, we need, as a society, to understand where the costs and benefits of our policy choices actually lie. On the assumption that knowledge may lead to power, being aware of and understanding these conflicts and the allocation of their costs is the first step toward a coherent and effective program of affordable housing development.

21 See, e.g., JURGen Habermas, Between facts AND NORMS: CONTRIBUtions to a DISCOURSE THEORY OF LAW AND DEMOCRACY (1998).

22 See, e.g., Derek Heater, What Is Citizenship? 44-79 (1999).

23 John RaWls, A Theory of Justice (1971). 


\section{Acknowledgements}

The author would like to thank his friend and colleague Peter Byrne for ongoing assistance in developing and refining this project and the participants in the Affordable Housing and Public-Private Partnerships: The Intersection of Housing, Property, and Real Estate at the University of Colorado Law School, particularly Robin Malloy and Nestor Davidson, for their comments and support. I also want to thank Aaron Schmitz for very able research assistance. 